Provincial High School and Normal School, and Principal Murray, of the University of Saskatchewan, took part. The University of Manitoba at present is hardly more than a group of science faculties supplementary to the arts courses provided in the affiliated denominational colleges. Alberta and Saskatchewan are laying the foundations of what will one day be strong State universities, and Dean Wesbrook did not disguise his opinion that this was the right course to pursue. In the course of the discussion Mr. C. R. Mann, secretary of Section L of the American Association for the Advancement of Science, spoke of the direct influence which the needs of the community at large must have upon the work of a State university.

Mr. W. M. Heller, a vice-president of the section, opened a symposium on practical work in schools with a paper on the report of the committee on practical studies, which was presented at Dublin last year. Dr. Kimmins contributed a paper on the London trade schools; Miss Lilian Clarke an address, illustrated with the lantern, on scientific nature-study in secondary schools; and Mr. W. Hewitt read a thoughtful paper on practical work in continuation schools and evening classes. Mr. Walter Sargent, of Chicago University, claimed a place in the primary-school curriculum for manual training for the purposes of industrial education. In many localities in America 80 per cent. of the children leave before the end of the primary course. These children drift into unskilled occupations, and spend often two or more years in employment which awakens no industrial interest and offers no vocational outlook. For these children an optional course should be provided, planned definitely to promote industrial efficiency. Those who argue that this would abridge the period of cultural education, already too short, were reminded that no sharp line can be drawn between cultural and industrial education. "Most of the activities which have raised men from savagery involved a utilitarian test of their result. Utilitarian is a word the meaning of which becomes more inclusive with advancing civilisation."

In the discussion on the teaching of geography Profs. Dodge, Johnston and Brigham, Mr. Chisholm, and Dr. C. H. Leete took part. To one trained in geography on the old topographical method, or want of method, who is watching its gradual displacement by the more scientific regional geography, it was novel to hear that in the high schools of the United States there is practically no serious study of regional geography. The physiographical text-books in use in America are admittedly much in advance of our own, but the advance appears to have been at the expense of the student, who, after his fourteenth year, is condemned to the study of classifications principally of land forms with reference to their origin rather than to their effect upon human and animal life. Happily, there are signs of change. Prof. Brigham's account of how he was driven back upon topography pure and simple in his endeavours to aid a young student of his own kin who was floundering in a text-book on physiography (very likely his own book!) amused his English hearers, and, it may be hoped, was not lost upon some of his brother professors across the water.

The closing discussion, on education as a preparation for Canadian life, was opened by the president, who proposes to test his theories on a farm for English publicschool boys which he is establishing in the neighbourhood of Calgary. He was followed by Mr. S. E. Lang with an account of high-school work in agriculture. Miss Benson described the household science course at Toronto University, and Miss Oakley gave an account of the similar course at King's College, London. Mr. Eggar spoke of the value of school games. If the principle that it was better to lose a game than to win it unfairly were true, then school games had a grand moral as well as a physical effect.

An account of the proceedings would be incomplete without some mention of the collection of brush drawings by pupils of the Village Hall School, Weybridge, which Mr. T. S. Marvin's pertinacity had brought intact through the Canadian customs. This interesting exhibit had been designed to help children in Canadian schools to realise the conditions of child life in England. There were series of brush drawings illustrating rooms in English houses, methods of going to school, bric-à-brac, portraits of the artists, and so on. Nature-study was illustrated by sketches of plants characteristic of the different months, and studies of the seasonal growth and decay of common wild flowers. The purpose of the drawings was excellent, and was carried out in a charming fashion. The naturestudy work reached a high standard of accuracy, and almost all the drawings showed great artistic merit. It is pleasant to think that the collection will remain in Manitoba to pay a double debt-as a token to the educators of the province of our gratitude for their efforts on our behalf and as a reminder to the children of their child cousins on the other side of the sea.

\section{CONFERENCE OF DELEGATES OF THE CORRESPONDING SOCIETIES, BRITISH ASSOCIATION}

I $F$ the annual conference of delegates of the local societies in correspondence with the British Association had been held at Winnipeg, it is not likely that many societies in this country could have sent representatives. It was consequently decided to hold an autumn conference in London, as was done after the South African meeting four years ago. Accordingly, a conference was held on Monday and Tuesday, October 25 and 26 , in the rooms of the Geological Society at Burlington House, under the chairmanship of Prof. A. C. Haddon, F.R.S. As many of the delegates from the provinces arrived in London on the preceding Saturday, an official visit to Kew Gardens was made on Sunday afternoon, when the delegates were received by Lieut.-Colonel Prain, F.R.S., and Dr. O. Stapf.

The conference was opened on Monday morning by an extemporaneous address from the chair, in which Dr. Haddon urged the local societies to carry out observational work of an original character. Regional surveys might well be undertaken. Intensive work in the special areas within range of the activities of the respective societies would ultimately lead to a close knowledge of the whole country. Dr. H. R. Mill's detailed study of a district in the south-east of England was naturally held up as a model; and reference was also made to the excellent work of Prof. A. W. Clayden on the origin of the scenery of Devonshire, and to that of Prof. W. W. Watts on Charnwood Forest. Turning to our rivers as a suitable subject for local study, Dr. Haddon referred to the work of Prof. W. M. Davis, remarking, incidentally, that it was rather strange an American should have to teach us how to read the story of our own streams. With regard to zoology, the chairman explained that when he worked under F. M. Balfour he was an enthusiastic embryologist. Notwithstanding the advance of special work in the higher departments, there was still ample room for the amateur in zoology. Anthropometry, again, was a subject that might well be taken up by the local societies.

A paper on national anthropometry was read by $\mathrm{Mr}$. $\mathrm{J}$. Gray, the secretary of the anthropometric committee of the British Association. He explained the methods of measurement, and exhibited on the screen the excellent figures prepared by the late Prof. Cunningham to define the exact points of reference on the living subject, from which measurements should be taken. The instruments used are inexpensive and their use not difficult, so that, in the absence of a national system of anthropometry by a Government department, the natural history societies in each county might well undertake the work. A demonstration was given, and many of the delegates were measured. Attention was also directed to the various means now used to estimate quantitatively certain mental faculties.

A prolonged discussion was initiated by Prof. Meldola, F.R.S., who desired to elicit from the delegates their opinion as to the expediency of establishing a fund, with Government aid or otherwise, for the purpose of assisting scientific societies in the publication of original work. Many societies were crippled by insufficient means, and it was believed that much good work in the country remained unpublished, or, if published, was insufficiently illustrated, whilst in many cases the proportion of income 
expended on publications was so great as to hinder the activity of the societies in other directions.

Sir Alexander Pedler, F.R.S., explained how the British Science Guild had sought to relieve the scientific societies by endeavouring to obtain a reduction in the rate of postage of their publications, but he much regretted that the Postmaster-General, though sympathetic, could not see his way to grant such relief. Some of the delegates suggested a renewal of the application, but it seemed unlikely that this would be successful. The general question of founding a publication fund was discussed by representatives of many scientific societies, including the Chemical, the Royal Astronomical, the Zoological, the Entomological, the Royal Anthropological Institute, and the Institution of Mining Engineers.

In a paper on the financial position of our local societies, Mr. John Hopkinson sketched the history of the Hertfordshire Natural History Society, and showed how a society which had always struggled with a small income had yet managed to publish excellent original work.

Although the opinion of the conference was generally favourable to the formation of a publication fund, a few speakers expressed the opinion that it would be inexpedient to take any step which might tend to increase the publications of local societies, inasmuch as the mass of such literature was already embarrassing to the bibliographer.

On the afternoons of Monday and Tuesday the delegates visited, under scientific guidance, the Natural History Museum and the Zoological Gardens.

\section{UNIVERSITY AND EDUCATIONAI} INTELLIGENCE.

CAMBRIDGE.--An election to the Clerk-Maxwell scholarship will take place at the end of this term. Candidates are requested to send in their names to Sir J. J. Thomson on or before December 1 .

Dr. G. H. F. Nuttall has been re-elected to the Quick professorship of biology. Mr. J. S. Gardiner has been elected to the professorship of zoology and comparative anatomy. Mr. E. O. Lewis has been appointed demonstrator of experimental psychology until Michaelmas, IgII; and Mr. D. G. Lillie has been elected to a Hutchinson research studentship for natural science.

Mr. H. F. Tiarks has supplemented Messrs. J. Henry Schröder and Co.'s gift of an endowment of a professorship of German by placing at the disposal of the University the sum of $5000 l$. for the endowment of one or more scholarships for the encouragement of the study of German in the University.

IT is announced in Science that Mr. Andrew Carnegie has subscribed 20,00ol. to McGill University as a part of the general fund of $400,000 l$. which friends of the University are trying to raise.

The Black Bear Press, Cambridge, has sent us a copy of the first issue of a new weekly magazine, the Gownsman, which is to be a record and comment of university life. The contents range over every department of university activity-academic, athletic, social-and the periodical should appeal to all Cambridge men, past and present. With this first issue is published, as a supplement, an excellently reproduced portrait of $\mathrm{Sir}$ Joseph Thomson, F.R.S. The price of the new publication is 2d. weekly.

THE annual meeting of the Association of Teachers in Technical Institutions will be held on November 6 at St. Bride Institute, Fleet Street, E.C. The chair will be taken at 3 p.m. by Mr. J. Wilson, who is the president of the association for the coming year. The report of the council will contain an abstract of the educational and professional work accomplished during the year. The educational work comprises the consideration of such questions as syllabuses in such subjects as applied mechanics and electrical engineering, the training of craftsmen, the preliminary training of technical students, and the Royal Commission on university and higher education in London.

In his inaugural address, at the beginning of the present session, the president of Harvard University, Dr. A. NO. 2088, VOL. 82]
Lawrence Lowell, discussed an ideal college training from three points of view. He considered the highest development of the individual student, the proper relation of the college to the professional school, and the relations of the students to one another. Each line of thought led him to the same conclusion. The best type of liberal education in our complex modern world aims at producing men who know a little of everything, and something well. The essence of a liberal education, said Dr. Lowell, consists in an attitude of mind, a familiarity with methods of thought, an ability to use information rather than a memory stocked with facts, however valuable such a storehouse may be. No method of ascertaining truth, and therefore no department of human thought, ought to be wholly a sealed book to an educated man. It has been truly said that few men are capable of learning a new subject after the period of youth has passed, and hence the graduate ought so to be equipped that he can grasp effectively any problem with which his duties or his interest may impel him to deal. In the present age some knowledge of the laws of nature is an essential part of the mental outfit which no cultivated man should lack. He need not know much, but he ought to know enough to learn more. To him the forces of nature ought not to be an occult mystery, but a chain of causes and effects with which, if not wholly familiar, he can at least claim acquaintance; and the same principle applies to every other leading branch of knowledge.

\section{SOCIETIES AND ACADEMIES. \\ PARIS.}

Academy of Sciences, October 26.-M. Bouchard in the chair.-E. L. Bouvier: The phenomena which characterise the change of nest in the ant Messor barbarus. A detailed account of the curious habits of these ants when exchanging nests.-M. Gouy: The constitution of the electric charge at the surface of an electrolyte.-Armand Gautier: Remarks on the second International Congress for the Repression of Fraud in Food and Drugs, held at Paris, October I8 to 23.-J. Guillaume: Observations of the sun made at the Observatory of Lyons during the second quarter of roog. Observations were possible on sixtythree days, the results being summarised in three tables showing the number of spots, their distribution in latitude, and the distribution of the faculæ in latitude.-Charles Nordmann: The temperature of $\beta$ Perseus (Algol). Taking $6000^{\circ}$ as the temperature of the sun, the application of Planck's law leads to $22,900^{\circ}$ as the temperature of Algol. This is nearly identical with the temperature $\left(2_{3}, 800^{\circ}\right)$ found previously by a totally independent method. -M. Javelle: Halley's comet. Observations of the comet made with the large equatorial at Nice. On October I2 it appeared as a small round nebulosity, ro $^{\prime \prime}$ to ${ }^{\prime \prime} 5^{\prime \prime}$ in diameter, with a central nucleus of the fourteenth to fifteenth magnitude.-R. Jarry-Desloges: Observations on the surface of the planet Mars. Two diagrams accompany this paper, showing the details perceived during July, August, and September, 1909.-G. Athanasiadis: The influence of temperature on the phenomena of polarisation in the electrolytic valve. The potential difference, producing a definite current in the electrolytic valve, diminishes as the temperature increases.-L. Gay: The vapour pressure of mixed liquids. A new demonstration and generalisation of the formula of Duhem-Margules.G. Belloc: The emission of gases by heated metals. A definite volume of gas can be extracted by heating a metal such as steel to a definite temperature in a vacuum. If the metal is allowed to cool, the vacuum being maintained, a re-heating to the same temperature after an interval of some days gives rise to a fresh amount of gas, and this process can be continued; even after seven heatings small amounts of gas continue to be evolved.-Maurice coste : The transformations of selenium. Exact measurements of the density of selenium submitted to various treatments have been made.-E. Cornec: Cryoscopic study of the neutralisation of some acids.-Maurice Barrée: The points of transformation of the copper-aluminium alloys as determined by a study of the variation of electrical resistance with temperature.-Georges Darzens and $M$. Rost: Hexahydrophenylacetylene and hexahydrophenylpropiolic acid. Starting this hexahydroacetophenone, 